\title{
Tectonic map and geologic evolution of Syria: The role of GIS
}

\author{
Graham BREW and Muawia Barazangl, Cornell University, Ithaca, New York, U.S. \\ TARIF SAWAF, Syrian Petroleum Company, Damascus, Syria \\ KHALED Al-MaleH, Damascus University, Damascus, Syria
}

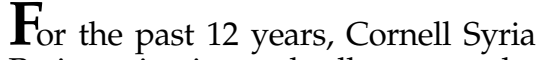
Project scientists and colleagues at the Syrian Petroleum Company have studied the regional structure and geologic evolution of Syria. We are currently generating new structural maps and tectonic models for the whole country. Information on this region is relatively limited, despite the local importance of hydrocarbon production and abundant surface and subsurface data. Our regional approach involves new interpretations of seismic reflection profiles, well data, remote sensing imagery, and potential-field data, merged with existing interpretations of similar data sets. These interpretations, integrations, analyses, and map preparation are all performed within a GIS platform.

As detailed elsewhere in this issue, the importance of GIS as a data storage and interrogation tool for petroleum exploration is well established. This article describes our use of GIS to facilitate regional tectonic mapping in Syria. Although not directly related to the search for hydrocarbons, the maps and models generated have obvious utility for oil exploration. Herein we detail the types of data being used, their integration and interpretation within the GIS, and our preliminary analysis and findings. We will show how a GIS approach eases data archiving and map generation and also provides interpretational possibilities not available with more traditional mapping procedures.

Our interpretations show that much tectonic deformation within Syria occurred within repeatedly reactivated "mobile zones." GIS-generated structural maps on various geologic horizons, and tectonic maps at key time points, illustrate the interconnected and contemporaneous nature of the tectonic episodes within the different Syrian mobile zones. Hydrocarbon plays in Syria, such as the Euphrates Fault System, owe their existence to these tectonic episodes; better understanding of the deformation will lead to more informed exploration strategies. Hence, the data stored within the GIS can directly influence exploration strategies and decisions.

Study area and GIS coverages. Our research concerns the northern Arabian Platform, specifically Syria and immediately surrounding areas (Figure 1). Past research by Cornell Syria Project scientists concerns the tectonic evolution of the different tectonic zones within Syria, as delineated in Figure 1. The previous studies established the timing and style of structural deformation within each zone. Previous attempts were made to correlate the findings; however, these past syntheses relied on fewer data than currently available, and a full integration of all available data and results was never attempted. In the current work we are taking a truly regional

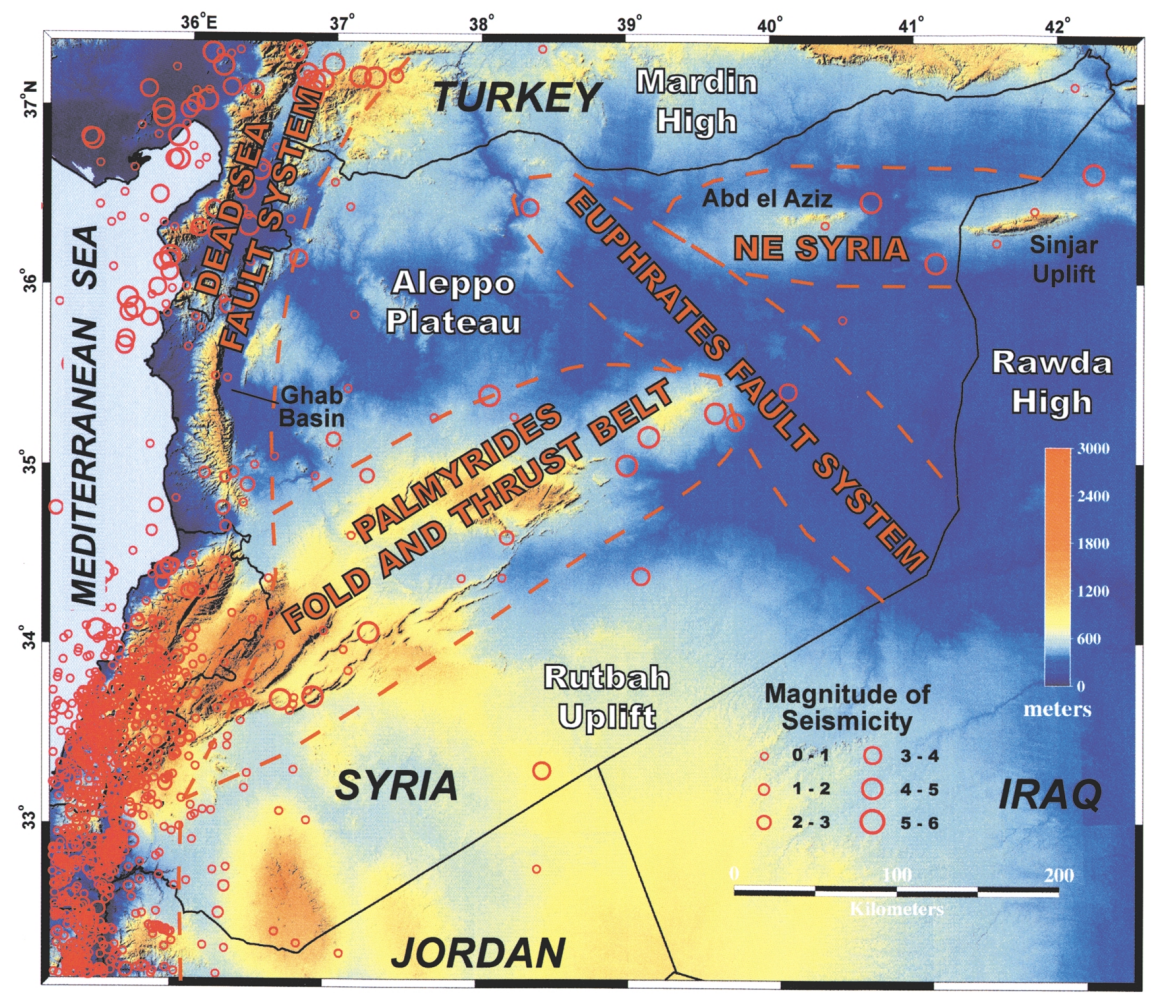

Figure 1. Topographic image of the northern Arabian Platform. Dashed red lines outline active tectonic "mobile zones" that are named in red. "Stable" platform blocks are in white. Also shown is the distribution of seismicity within the northern Arabian Platform as taken from the International Seismological Center (ISC) database for 1964-1994 (see Table 1). Note that the apparent lack of seismic activity along the Dead Sea fault system in western Syria is likely a consequence of uneven seismic station coverage. 

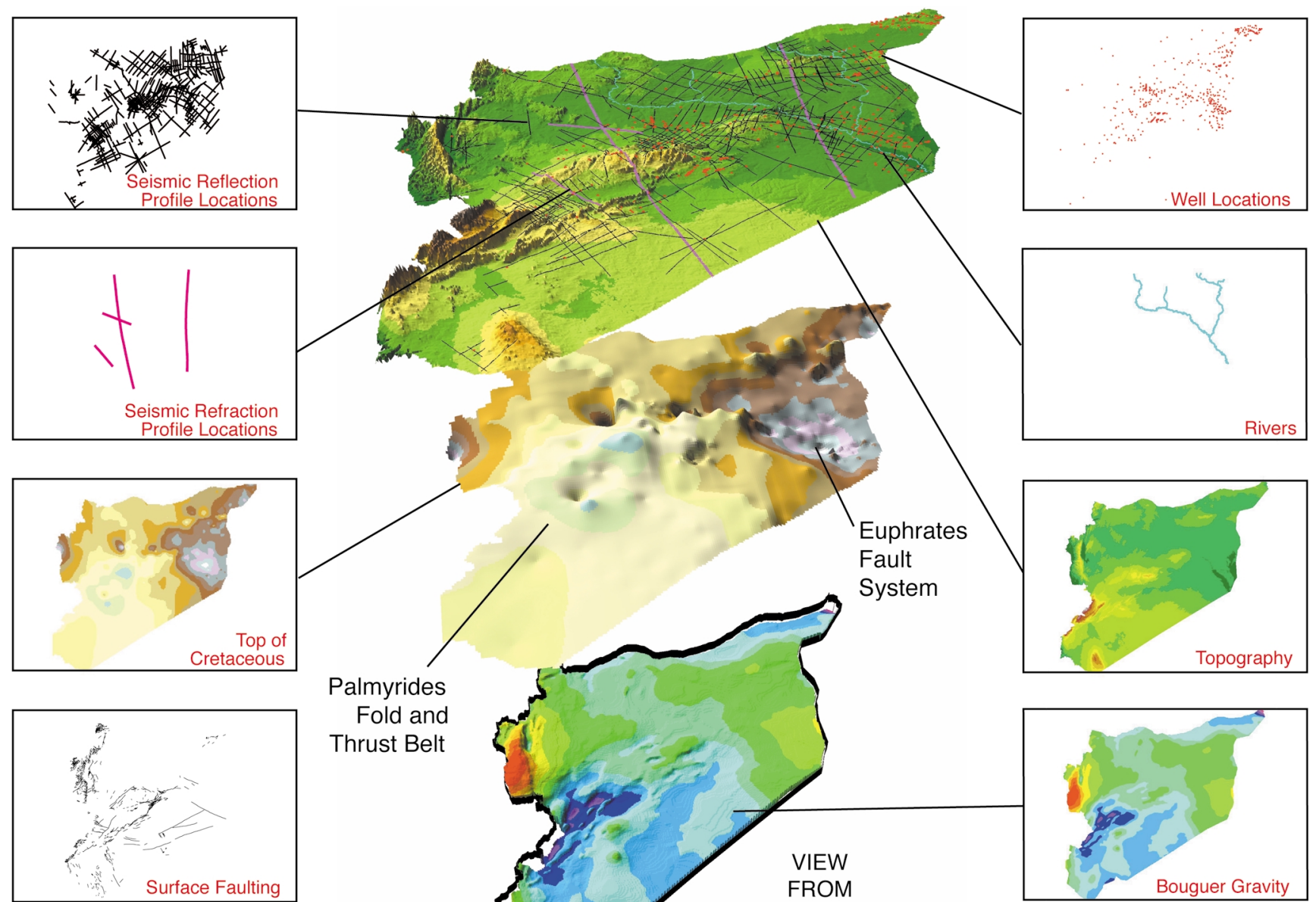

Palmyrides

Fold and

Thrust Belt

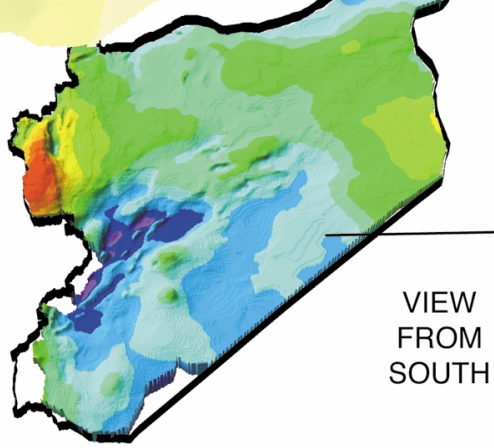

Topography

Figure 2. Composite image of selected coverages available at Cornell from within the GIS including a 3-D perspective view of Syria showing data locations.

records, and scanning these records into the GIS remains a task for the future). Table 1 details the coverages within the GIS we are creating, distinguishing among the three types. Some metadata (data about the data) for the coverages are also shown in Table 1, including original source and scale, quantity or extent of the coverage (e.g., kilometers of seismic data), and so on. We are using ESRI (Environmental Systems Research Institute) products, namely Arc/INFO and ArcView, for most of our work, so this discussion follows ESRI nomenclature.

Understandably, the coverages have varied provenance. Some have been digitized at Cornell from published sources, some are downloaded from Internet archives, and others are the products of our interpretations. During the construction of the coverages, strict quality control ensures the highest accuracy both within and among data sets. This means establishing original map projection parameters, careful digitization, meticulous registration, and cross-checks.
Presently we use the Levant Lambert projection for most of our work, although a reprojection of the coverages is trivial.

Storing data within a GIS has tremendous advantages in comparison with hard-copy records or independent computer data bases. Once all the data are entered, data access becomes much faster. For instance, finding all gamma-ray logs recorded within Silurian shale or locating all seismic lines processed beyond $4 \mathrm{~s}$ two-way time becomes elementary. Similarly, adding new data is quick and easy, with the impact of new information on any given interpretation instantly accessible. Fence diagrams, isopachs, grids, cross-sections, animations, and other interpretable products are easily created. Furthermore, as shown in the following examples, a workstation-based GIS interpretation permits a 3-D appreciation of the situation and frees the user from the constraints of a traditional "profile-based" 


\begin{tabular}{|c|c|c|c|c|c|c|c|}
\hline & $\begin{array}{l}\text { COVERAGE } \\
\text { TYPE }\end{array}$ & COVERAGE & $\begin{array}{c}\text { SOURCEI } \\
\text { REFERENCE }\end{array}$ & $\begin{array}{l}\text { ORIGINAL } \\
\text { SCALE }\end{array}$ & $\begin{array}{l}\text { QUANTITYI } \\
\text { EXTENT }\end{array}$ & $\begin{array}{l}\text { FEATURE } \\
\text { TYPE }\end{array}$ & $\begin{array}{l}\text { SPECIAL } \\
\text { NOTES }\end{array}$ \\
\hline \multirow{11}{*}{ 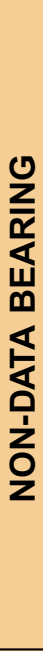 } & \multirow{2}{*}{$\begin{array}{l}\text { Seismic } \\
\text { Data } \\
\text { Locations }\end{array}$} & $\begin{array}{l}\text { Seismic } \\
\text { Reflection }\end{array}$ & Industry Basemaps & $1: 200000$ & $\sim 17000 \mathrm{~km}$ & Arcs and Points & - \\
\hline & & $\begin{array}{l}\text { Seismic } \\
\text { Refraction }\end{array}$ & Basemap & $1: 500000$ & $\sim 875 \mathrm{~km}$ & Arcs & - \\
\hline & \multirow{6}{*}{$\begin{array}{c}\text { Cultural } \\
\text { Data }\end{array}$} & $\begin{array}{l}\text { International } \\
\text { Borders }\end{array}$ & $\begin{array}{c}\text { DCW } \\
\text { www.esri.com }\end{array}$ & $1: 1000000$ & Global & Arcs & - \\
\hline & & Urban Areas & $\begin{array}{c}\text { DCW } \\
\text { www.esri.com }\end{array}$ & 1:1 000000 & Global & Polygons & - \\
\hline & & Roads & $\begin{array}{c}\text { DCW } \\
\text { www.esri.com }\end{array}$ & 1:1 000000 & Global & Arcs & - \\
\hline & & Rail Roads & $\begin{array}{c}\text { DCW } \\
\text { www.esri.com }\end{array}$ & $1: 1000000$ & Global & Arcs & - \\
\hline & & Lakes & $\begin{array}{c}\text { DCW } \\
\text { www.esri.com }\end{array}$ & $1: 1000000$ & Global & Polygons & - \\
\hline & & Rivers & $\begin{array}{c}\text { DCW } \\
\text { www.esri.com }\end{array}$ & 1:1 000000 & Global & Arcs & - \\
\hline & \multirow{2}{*}{$\begin{array}{l}\text { Hydrocarb. } \\
\text { Production }\end{array}$} & $\begin{array}{l}\text { Field } \\
\text { Locations }\end{array}$ & Various & $1: 500000$ & Syria & Polygons & $\begin{array}{l}\text { Production, } \\
\text { Pay Zone etc. }\end{array}$ \\
\hline & & Pipelines & Various & $1: 500000$ & Syria & Arcs & - \\
\hline & \multirow{2}{*}{ Well Data } & $\begin{array}{l}\text { Well Locations } \\
\text { and Formation Tops }\end{array}$ & Various & Various & $\begin{array}{l}\text { Nearly } 400 \\
\text { Wells }\end{array}$ & Points & $\begin{array}{l}\text { Selected Log Data } \\
\text { to be included }\end{array}$ \\
\hline \multirow{10}{*}{ 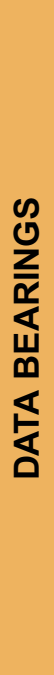 } & & $\begin{array}{c}\text { Facies } \\
\text { Information }\end{array}$ & Well Logs & - & $\begin{array}{l}\text { Selected Wells } \\
\text { from Syria }\end{array}$ & - & $\begin{array}{l}\text { From Well } \\
\text { Logs }\end{array}$ \\
\hline & \multirow{2}{*}{$\begin{array}{l}\text { Potential } \\
\text { Field Data }\end{array}$} & $\begin{array}{l}\text { Bouguer Gravity } \\
\text { Anomalies }\end{array}$ & BEICIP (1975) & Various & Syria, Lebanon & Grid and Arcs & $\begin{array}{l}2 \mathrm{mGal} \\
\text { Resolution }\end{array}$ \\
\hline & & $\begin{array}{l}\text { Aeromagnetic } \\
\text { Anomalies }\end{array}$ & Filatov (1958) & $1: 500000$ & Syria & Grid and Arcs & $\begin{array}{c}25 \mathrm{nT} \\
\text { Resolution }\end{array}$ \\
\hline & \multirow{2}{*}{ Imagery } & $\begin{array}{l}\text { Landsat } \\
\text { Thematic Maper }\end{array}$ & $\begin{array}{l}\text { Eros Data Center } \\
\text { edcwww.cr.usgs.gov }\end{array}$ & $\begin{array}{l}\sim 30 \mathrm{~m} \text { Ground } \\
\text { Resolution }\end{array}$ & See Figure 4 & Grid & $\begin{array}{l}\text { Seven Spectral } \\
\text { Bands }\end{array}$ \\
\hline & & Topography & $\begin{array}{l}\text { GTOPO30 } \\
\text { Gesch et al. (1999) }\end{array}$ & $\begin{array}{l}\sim 1 \mathrm{~km} \text { Ground } \\
\text { Resolution }\end{array}$ & Global & Grid & $\begin{array}{l}\text { Bathymetry } \\
\text { also Available }\end{array}$ \\
\hline & \multirow{8}{*}{$\begin{array}{l}\text { Geology I } \\
\text { Tectonics }\end{array}$} & $\underset{\text { Map }}{\text { Geologic }}$ & $\begin{array}{l}\text { Field Mapping } \\
\text { Ponikarov (1966) }\end{array}$ & $1: 500000$ & $\begin{array}{l}\text { Syria, Turkey, } \\
\text { Lebanon }\end{array}$ & Polygons & - \\
\hline & & Seismicity & $\begin{array}{l}\text { ISC Dataset } \\
\text { www.isc.ac.uk }\end{array}$ & - & $\begin{array}{l}\sim 22000 \text { events } \\
\text { for study Area }\end{array}$ & Points & - \\
\hline & & $\begin{array}{l}\text { Earthquake Focal } \\
\text { Mechanisms wu }\end{array}$ & $\begin{array}{l}\text { Harvard CMT } \\
\text { w.seismology.harvard.edu }\end{array}$ & - & - & Points & $\underset{>\sim 5}{\text { For Magnitudes }}$ \\
\hline & & Volcano Locations & $\begin{array}{l}\text { Ponikarov (1966) } \\
\text { and Others }\end{array}$ & $1: 500000$ & Syria, Turkey & Points & $\begin{array}{l}\text { Ages also } \\
\text { Available }\end{array}$ \\
\hline & & $\begin{array}{l}\text { Detailed } \\
\text { Field Observations }\end{array}$ & Various & 1:1000 & $\begin{array}{l}\text { Palmyrides/ } \\
\text { Coastal ranges }\end{array}$ & - & $\begin{array}{l}\text { Detailed Surface } \\
\text { Sections }\end{array}$ \\
\hline \multirow{14}{*}{ 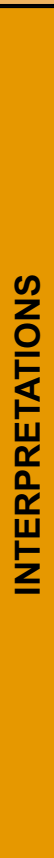 } & & $\begin{array}{l}\text { Tectonic Domain } \\
\text { Boundaries }\end{array}$ & $\begin{array}{c}\text { Cornell } \\
\text { Interpretation }\end{array}$ & - & $\begin{array}{l}\text { Northern Arabian } \\
\text { Platform }\end{array}$ & Polygons & - \\
\hline & & Surface Folding & $\begin{array}{l}\text { Ponikarov (1966) and } \\
\text { Image Interpretations }\end{array}$ & $1: 500000$ & Syria & Arcs & - \\
\hline & & Surface Faulting & $\begin{array}{l}\text { Ponikarov (1966) and } \\
\text { Image Interpretations }\end{array}$ & $1: 500000$ & Syria & Arcs & - \\
\hline & \multirow{7}{*}{$\begin{array}{c}\text { Structural } \\
\text { Maps }\end{array}$} & Top Paleogene & $\begin{array}{l}\text { Cornell } \\
\text { Interpretations }\end{array}$ & $1: 500000$ & Syria & Grid and Arcs & $\begin{array}{l}\text { Fault Activity, } \\
\text { throw etc. }\end{array}$ \\
\hline & & Top Cretaceous & $\begin{array}{c}\text { Cornell } \\
\text { Interpretations }\end{array}$ & $1: 500000$ & Syria & Grid and Arcs & $\begin{array}{l}\text { Fault Activity, } \\
\text { throw etc. }\end{array}$ \\
\hline & & $\begin{array}{l}\text { Top Lower } \\
\text { Cretaceous }\end{array}$ & $\begin{array}{c}\text { Cornell } \\
\text { Interpretations }\end{array}$ & $1: 500000$ & Syria & Grid and Arcs & $\begin{array}{l}\text { Fault Activity, } \\
\text { throw etc. }\end{array}$ \\
\hline & & Top Triassic & $\begin{array}{c}\text { Cornell } \\
\text { Interpretations }\end{array}$ & $1: 500000$ & Syria & Grid and Arcs & $\begin{array}{l}\text { Fault Activity, } \\
\text { throw etc. }\end{array}$ \\
\hline & & Top Paleozoic & $\begin{array}{c}\text { Cornell } \\
\text { Interpretations }\end{array}$ & $1: 500000$ & Syria & Grid and Arcs & $\begin{array}{l}\text { Fault Activity, } \\
\text { throw etc. }\end{array}$ \\
\hline & & Top Mid-Cambrian & $\begin{array}{c}\text { Cornell } \\
\text { Interpretations }\end{array}$ & $1: 500000$ & Syria & Grid and Arcs & $\begin{array}{c}\text { Prominent } \\
\text { Seismic Reflector }\end{array}$ \\
\hline & & $\begin{array}{l}\text { Top Metamorphic } \\
\text { Basement }\end{array}$ & $\begin{array}{c}\text { Cornell } \\
\text { Interpretations }\end{array}$ & $1: 500000$ & Syria & Grid and Arcs & $\begin{array}{l}\text { Predominantly from } \\
\text { Refraction Analysis }\end{array}$ \\
\hline & \multirow{4}{*}{$\begin{array}{c}\text { Sed./Strat. } \\
\text { Analysis }\end{array}$} & Isopachs & Interpreted & $1: 500000$ & $\begin{array}{l}\text { Syrian Mesozoic } \\
\text { Section }\end{array}$ & Arcs & $\begin{array}{l}\text { Future } \\
\text { Project }\end{array}$ \\
\hline & & $\begin{array}{l}\text { Facies } \\
\text { Variation }\end{array}$ & Interpreted & $1: 500000$ & $\begin{array}{l}\text { Syrian Mesozoic } \\
\text { Section }\end{array}$ & Arcs & $\begin{array}{l}\text { Future } \\
\text { Project }\end{array}$ \\
\hline & & Paleogeography & Interpreted & $1: 500000$ & $\begin{array}{l}\text { Syrian Mesozoic } \\
\text { Section }\end{array}$ & Arcs & $\begin{array}{l}\text { Future } \\
\text { Project }\end{array}$ \\
\hline & & $\begin{array}{l}\text { Source Rock } \\
\text { Potential etc. }\end{array}$ & Interpreted & $1: 500000$ & $\begin{array}{l}\text { Syrian Mesozoic } \\
\text { Section }\end{array}$ & Arcs & $\begin{array}{l}\text { Future } \\
\text { Project }\end{array}$ \\
\hline
\end{tabular}


analysis.

Figure 2 is a simple demonstration of how selected coverages can be visualized. On a workstation, these perspective views are far more revealing than this paper reproduction; user interaction allows examination from any angle, with appropriate processing to highlight specific features. The top of Cretaceous surface was made by gridding only well data. Because seismic and other data have yet to be incorporated into this surface, faults are not shown. Relationships among topography, subsurface structure, and gravity response are apparent even in this preliminary view.

The utility of 3-D montages such as Figure 2 goes far beyond simple presentations. Figure 3 shows how surface, subsurface, and potential-field data may be used together. This type of GIS visualization allows observation of along-strike variations and subsequent modifications that are not possible when working on profile-type models. Another use of a 3-D perspective view might be to show surface geology draped over topography, thus illustrating patterns of erosion.

As part of the current regional work, we are interpreting tectonic features visible on Landsat Thematic Mapper (TM) images to aid structural mapping. GIS is particularly useful when interpreting remote sensing imagery, as the image can be viewed on screen and coregistered coverages overlain to aid interpretation. For example, known faults and folds mapped in the field can be overlain along with surface geology to establish the spectral and spatial characteristics of the various features and hence guide the interpretation. High-resolution digital topography can further guide fault mapping. Topography can be used with bedding traced from imagery to calculate regional bedding attitudes (the "three-point problem").

The Cornell University library of Landsat Thematic Mapper images for the Middle East includes the equivalent of more than 115 individual TM scenes. Many others are available for North Africa and other locations (Figure 4). For further information see http://atlas.geo.cornell.edu/htmls/TM/ mena.html.

Construction of structural maps. Construction of the structural maps listed in Table 1 is at a scale of 1:500 000. Figure 5 shows a preliminary example. The contours of depth to Lower Cretaceous are based on well data, together with digitized, depth- converted, seismic-reflection interpretations that have been entered into the GIS. Faults are interpreted from seismic reflection profiles and other data and their digitized locations entered into the GIS. Both the depth contours and the faults can be edited on screen. In this way, coregistered topography,

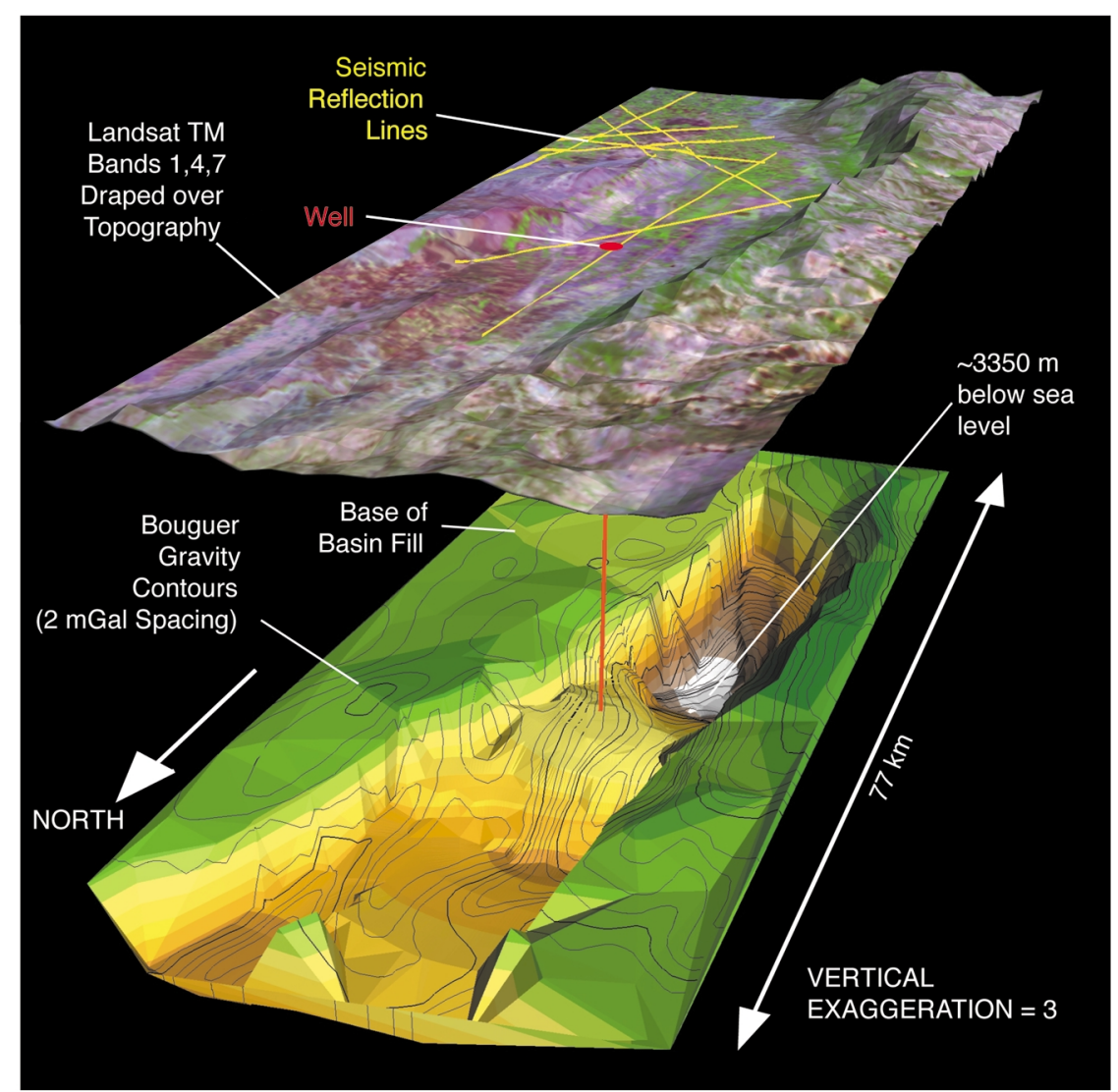

Figure 3. TM imagery draped on topography of the Ghab Basin region (see Figure 1), northwest Syria, and basin morphology. The lower surface has been lowered relative to its true position for ease of viewing. The Bouguer gravity contours generally exhibit distinct lows near the deepest portions of the basin. The occasional offset between gravity lows and basement is owing to depocenter migration with time. Note the asymmetric deposition within the basin and the segmentation of the deposition into smaller subbasins.

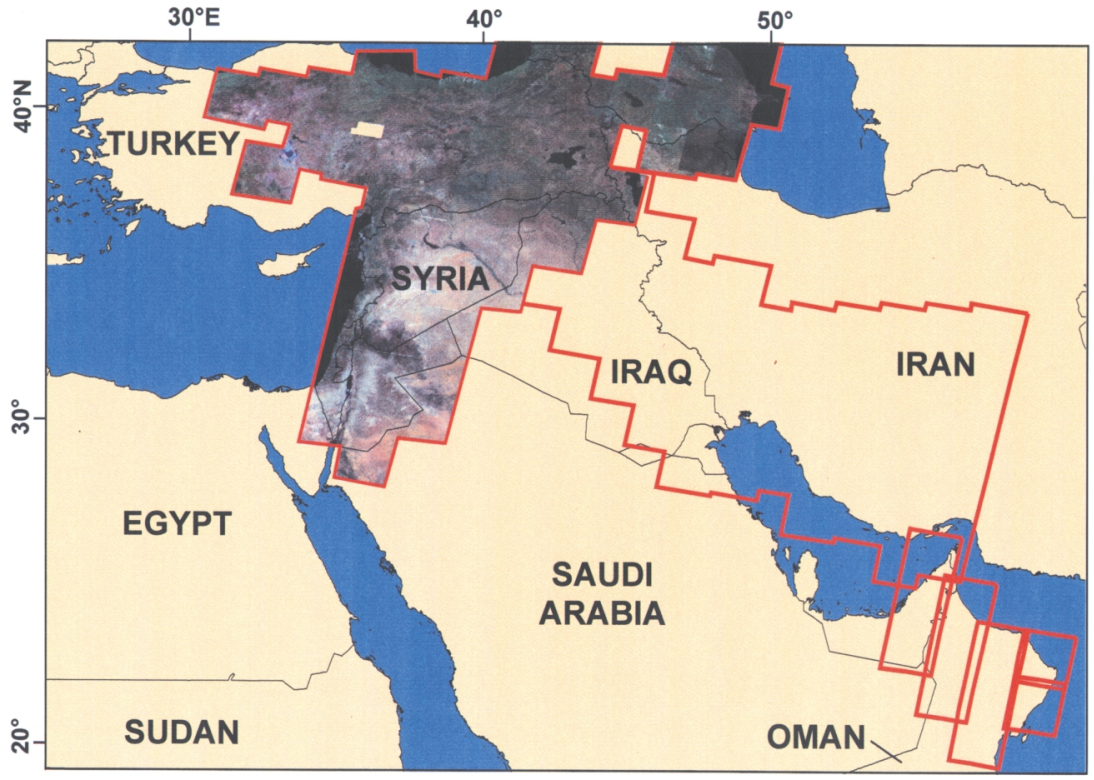

Figure 4. Preview image of some Middle East Landsat TM images stored at Cornell GIS. Red lines indicate locations of other images at Cornell. 
Figure 5.

Preliminary

structural

map show-

ing the top

of Lower

Cretaceous

horizon.

This is one

of a series of subsurface structural maps under construction within the

GIS (see

Table 1).
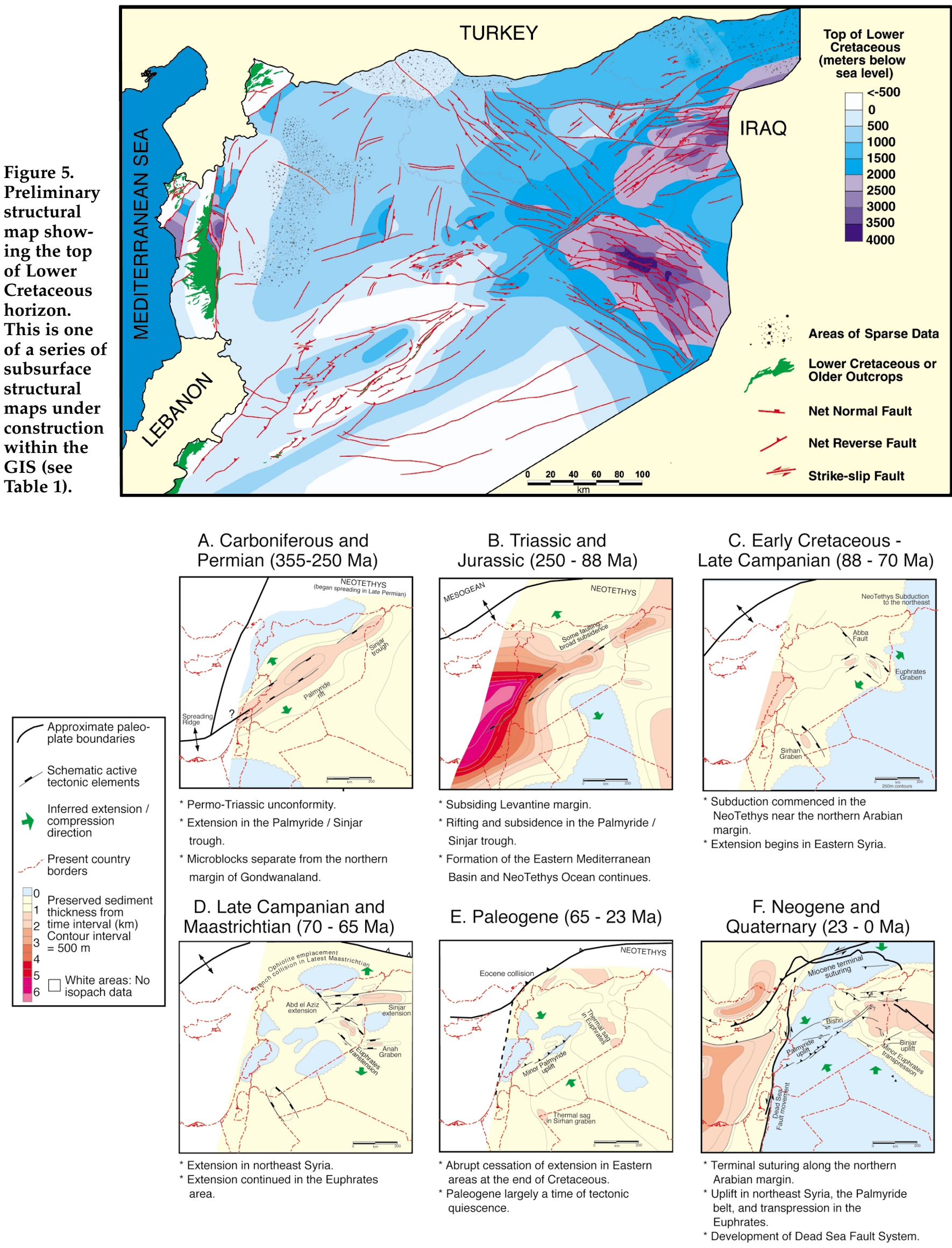

Figure 6. Preliminary maps showing schematic tectonic evolution of Syria. The six time frames illustrate dominant tectonic events and features at each of those time points. Once complete, the GIS will hold sufficient attributes to automatically generate maps such as these. 
satellite imagery, and geology maps can facilitate mapping of features.

Each fault, such as those shown in Figure 5, will be assigned extensive attributes within the coverage. Among these will be the probable timing and sense of motion on each fault. This information is important because many faults within Syria have experienced a variety of motions throughout their history. The attributes will also include the observational basis for the interpretation (e.g., seismic reflection, surface geology, gravity, etc.) and the confidence of the interpretation on, for instance, a scale of 1-5.

Gravity and magnetic data can help interpret areas where seismic data are insufficient. Using the GIS, it is easy to extract profiles or regions to be modeled, export them to a potentialfield modeling package, and integrate the results back to the GIS when the modeling is complete. A specific example would be the construction of an interface to export surfaces, well data, and other constraints to a 3-D GIS modeling package. (See "Suggestions for further reading" for more information.)

Spatial analysis is one of the key strengths of GIS. For instance, we could perform a spatial comparison between seismicity and mapped fault locations to assess the possible activity along a fault or group of faults. Unfortunately, this would require better earthquake locations than currently available. These may be possible in the near future with improved operation of the new Syrian seismic network.

Tectonic model. The final goal of our interpretations is construction of a tectonic model for the Phanerozoic evolution of the northern Arabian Platform. Figure 6 shows a preliminary version of such a model and Figure 7 the corresponding timing of events. Naturally, as our analyses continue, this model will become more robust and refined. This is a relatively easy task if all information and processing is within the GIS platform.

The isopachs in Figure 6 have been drawn within the GIS from well data, some seismic reflection constraints, and other information from published literature for areas outside Syria. While schematic in Figure 6, in the final construction of this model, the "active tectonic elements" in each time frame will be based on the attributes of fault activity within the GIS; i.e., faults attributed with normal fault movement in the Late Cretaceous will be shown with the appropriate symbols in the Late Cretaceous time frame.

In summary, our model shows that episodes of tectonic deformation experienced by the Arabian Platform have been caused by activity on nearby plate boundaries. The forces resulting from these activities are manifest in the repeated reactivation of tectonic zones within the platform. These "weak" tectonic zones are possibly suture zones relic from the Pan African accretion of the Arabian plate and still form the locus of deformation and tectonic activity in Syria today. Separating these tectonic zones are large stable areas that have experienced little deformation. Examination of Figure 5, for instance, shows the concentration of structures within the tectonic zones as defined in Figure 1, with limited deformation outside of these zones. Attributes of the faults clearly indicate repeated reactivation in various senses throughout time.

Although Early Paleozoic deformation is poorly represented in the GIS owing to data-quality issues, an unconformity of Late Silurian and Devonian age is observed regionally in well data. This is possibly related to the formation of the PaleoTethys Ocean. Subsidence curves constructed from well and seismic data indicate that since the Carboniferous, the northern Arabian Platform underwent a series of extensional periods associated with subsidence and rifting, resulting in large sedimentary accumulations. The Palmyride/Sinjar trough formed during Carboniferous time, possibly as a result of stress reorganizations on the Laurussian margins. The more significant rifting in the Palmyrides in Permian time was coincident with the separation of the Cimmerian block from Gondwana. This separation eventually led to the demise of the PaleoTethys Ocean, as the NeoTethys formed through accretion off the northeastern margin of Gondwana (Figure 6a). The formation and expansion of the NeoTethys in the Permian and Early Mesozoic was concurrent with the early stages of rifting in the Eastern Mediterranean and rifting in the Palmyrides. The growth of the Mediterranean Basin and NeoTethys continued episodically throughout the Early Mesozoic, accompanied by rifting and subsidence in the Palmyride and Sinjar areas (Figures $6 \mathrm{~b}$ and 7 ), that were possibly an aulacogen at this time.

Consumption of the NeoTethys started in the mid-Mesozoic and by mid-Cretaceous time a subduction zone had formed near the northeastern margin of Arabia (Figure 6c). Widespread extension in the Sinjar and Euphrates areas in the latest Cretaceous is evidenced by the large numbers of normal faults there active at that time (Figure 5). This extension is thought to be a consequence of reorganized subduction in the NeoTethys

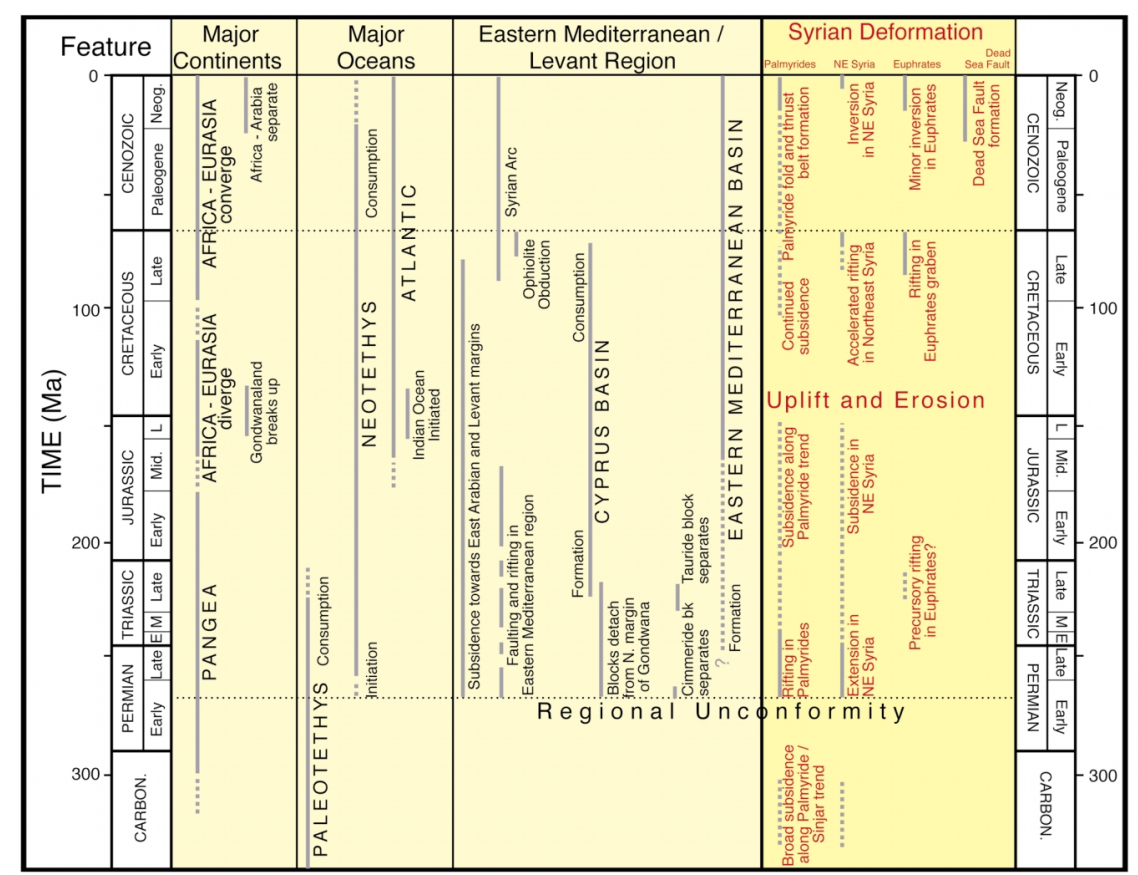

Figure 7. Summary chart showing the relative timing in the geologic evolution of the eastern Mediterranean in general and Syria in particular. Note the penecontemporaneous nature of many of the tectonic events throughout the region. 
(Figure 6d), while abrupt cessation of this extension at the end of the Cretaceous is probably a consequence of continental collision with the trench (Figure 6e). Significant reverse motion on the older normal faults is first observed in western areas around Middle Miocene time, progressing eastward, and leading to inversion in northeastern Syria in Pliocene time (Figure 6f). This sequence can be closely correlated with the terminal closure of the NeoTethys and suturing of Arabia to Eurasia, in concert with the opening of the Red Sea.

Sedimentary analysis and hydrocarbon exploration. The work discussed here is mostly concerned with structures and tectonics. A more complete integration of sedimentalogic and stratigraphic data could better define tectonic episodes and paleogeography by contributing information about water depth, source areas, and so forth. Detailed field observations in the Palmyride fold and thrust belt and the Syria Coastal Ranges, in addition to large numbers of subsurface lithological descriptions from drilling records, make such a synthesis possible.

We are currently integrating recent outcrop stratigraphic observations into the GIS. These additional data allow for more accurate production of isopachs, facies maps, paleogeographic reconstructions, and basin analyses that we eventually hope to complete for all areas of Syria. The Mesozoic section is the first target of this study owing to its overwhelming economic importance in the northern Arabian Platform.

Syria has a long history of hydrocarbon production. The currently produced $550000 \mathrm{~b} / \mathrm{d}$ come from three of the tectonic zones that we have discussed - the Palmyride fold and thrust belt, northeast Syria, and, most importantly, the Euphrates fault system. The tectonic episodes that we have discussed have been critical to the formation of these hydrocarbon reserves. For example, the phase of Late Cretaceous extension in eastern Syria was when many of the source rocks for that area were deposited. The subsidence associated with this and other tectonic events also permitted the burial of the source rocks deep enough for hydrocarbon generation. Additionally, the faulting was instrumental in the formation of many traps. The periods of tectonic compression experienced in Cenozoic time throughout Syria have been critical to trap formation in the northeast area, and for some

\section{Palmyride fields.}

Our continuing effort to map the structure and tectonic history of Syria will help to focus future hydrocarbon exploration efforts in the country. Furthermore, with the completion of our planned work to map the sedimentary and stratigraphic characteristics of the Syrian Mesozoic section, the benefit of this work for hydrocarbon exploration will become more apparent. The interrogation capabilities of the GIS excel when used in hydrocarbon exploration. When all the coverages are built, it will be simple to select, for example, all areas where Lower Cretaceous sandstone is more than 20-m thick, adjacent to faulting, and proximal to a potentially mature source rock. The wells within such areas could then be evaluated for their exploration successes, and undrilled areas could be identified. Once the necessary coverages are in place, this could all be performed in a matter of minutes.

Conclusions. GIS is an essential component in our current tectonic mapping of the northern Arabian Platform. Data manipulation, visualizations, and integrated interpretations, previously prohibitively time-consuming or impossible, are quick and easy using this technology. This allows faster, more accurate analysis, and better-quality, highly accessible, end products. The maps and models we are creating are important for continued hydrocarbon exploration within Syria and surrounding areas.

This work is still in progress, and some ideas discussed in this article are not yet implemented. Once our regional mapping of Syria is complete, we envisage Internet or CD-ROM publication, in addition to paper distribution, to allow digital distribution of various coverages. See $h t t p: / / a t l a s . g e o$. cornell.edu/syria/welcome.html for updates regarding this project.

Suggestions for further reading. "Middle East tectonics: Applications of GIS" by Seber et al. (GSA Today, 1997) introduces some of the more extensive Web-based GIS development at Cornell University; also see http://atlas.geo.cornell. $e d u$. "Geophysical and geological databases and CTBT monitoring: A case study of the Middle East" by Barazangi et al. (in Monitoring a CTBT, 1996) further details GIS activities at Cornell. "The petroliferous Euphrates graben system, Southeast Syria" by Litak et al. (AAPG Bulletin, 1998) and "Tectonic evolution of Northeast Syria: Regional tec- tonics and hydrocarbon implications" by Brew et al. (GeoArabia, 1999) describe detailed tectonic research conducted at Cornell. "Interactive visualization and modification of 3-D models using GIS functions" by Schmidt and Götze (Physical Chemistry of the Earth, 1998) describes the use of 3-D geoscience modeling, especially in respect to potentialfield data. $\mathbb{E}$

Acknowledgments: The Cornell authors thank Syrian Petroleum Company (SPC) for the generous provision of much of the data described here. Thanks to ARCO and Conoco for financial support at Cornell, and to many colleagues in Ithaca and Damascus for help and suggestions. In particular we thank Dogan Seber for his extensive efforts in GIS development and research at Cornell.

Graham Brew is finishing his Ph.D. in geophysics at Cornell University under the direction of Muawia Barazangi. His research with the Cornell Syria Project is focused on the interpretation of Syrian tectonic history through geophysical analysis. He obtained a B.Sc. in geophysics from University College, London, and worked for a short time with RTZ Mining and Exploration in Santiago, Chile.

Muawia Barazangi is a professor in the Department of Geological Sciences at Cornell, associate director of the Institute for the Study of the Continents (INSTOC), and leader of the Cornell Syria Project. His academic background includes a B.S. degree in physics and geology from Damascus University, Syria, an M.S. degree in geophysics from the University of Minnesota, and a Ph.D. in seismology from Columbia University's Lamont-Doherty Earth Observatory. His research history includes global tectonics, seismotectonics of continental collision zones, intracontinental mountain belts, and Middle East tectonics.

Tarif Sawaf currently works for the Al-Furat oil company in Syria while seconded from the Syrian Petroleum Company. Previously he was a senior geologist and associate head of the regional mapping department for the Syrian Petroleum Company. Before that he worked for seven years with Sonatrach, Algeria. His academic background includes a B.S. degree in applied geology from Damascus University, Syria.

Khaled Al-Maleh is professor in the Geology Department of Damascus University. His career has included time as head of Geology Department, Damascus University, head of the Division of Nuclear Ores Exploration with the Syrian Atomic Energy Commission, and general director of the Syrian General Establishment of Geology and Mineral Resources. He has published widely in French, Arabic, and English, and is currently focused on issues of the Mesozoic development of Syria, especially in relation to phosphate deposition.

Corresponding author: G. Brew, brew@geology.cornell.edu 